IJAMSR 2 (2) www.ijamsr.com CrossRef: https://doi.org/10.31426/ijamsr.2019.2.2.1221

International Journal of Advanced Multidisciplinary Scientific Research (IJAMSR) ISSN:2581-4281

\title{
EVALUATION OF IRANIAN TENTH GRADE HIGH SCHOOL ENGLISH TEXTBOOK
}

\author{
Fatemeh Roshani ${ }^{1}$, Servat Shirkhani ${ }^{2}$ \\ ${ }^{1}$ Dept. of. Language Teaching, Electronic Branch, Islamic Azad University, \\ Tehran, Iran \\ ${ }^{2}$ Dept.of. Language Teaching, Khorramabad Branch, Islamic Azad \\ University, Khorramabad, Iran \\ Email: irangreat2015@gmail.com
}

Keywords: Language Teaching Materials, Evaluation, Materials Evaluation, Textbook

\section{A B S T RA C T}

The present study was an attempt to evaluate the English textbook taught at Iranian high schools for the tenth grade. To perform this, 80 female and male high school teachers who taught the tenth grade high school English textbook in Tehran, Iran were selected to participate in this study. Most of the participants were educated in teaching English as a foreign language major course (TEFL) during their higher education. The teachers were selected from different high schools such as Narjes, Jami, Hannan, and Farzanegan high schools in Tehran. To conduct the research in practice, the participants were asked to complete a textbook evaluation questionnaire (Beydokhtinezhad, Azarnoosh, \& Abdolmanafi-Rokni, 2015). Then, 20 of the participating teachers were selected randomly and interview based on the interview protocol. Having collected raw data, descriptive statistics under the Statistical Package for the Social Sciences (SPSS) version 23 was run in order to analyze the teachers' responses to each of the items on the questionnaire.

Citation: Fatemeh Roshani, Servat Shirkhani, (2019). Evaluation Of Iranian Tenth Grade High School English Textbook: International Journal of Advanced Multidisciplinary Scientific Research (IJAMSR) ISSN:2581-4281, 2 (2), February, 2019, \# Art.1221, pp 101-122 
IJAMSR 2 (2) www.ijamsr.com CrossRef: https://doi.org/10.31426/ijamsr.2019.2.2.1221

\section{International Journal of Advanced Multidisciplinary Scientific Research (IJAMSR) ISSN:2581-4281}

\section{Introduction}

In the process of teaching and learning, textbooks are of great value and effect. Textbooks are considered an essential component of any English as a foreign language (EFL) course, so that the use of EFL, published materials is more widespread than ever (Zohrabi, Sabouri, \& Behroozian, 2012). In practice, textbooks serve teachers with guidelines concerning syllabi, teaching methodologies, and the materials to be taught. In order to select the best appropriate text, material developers should pay special attention to developing teaching materials. Textbooks are valuable in each language classroom, have several roles in English Language Teaching (ELT) curriculum, and help the process of language teaching and learning. A textbook has a very vital role in teaching and learning of English. Textbooks are the main sources that can transfer the knowledge and information to the learners in an easy and organized way (Ahour \& Ahmadi, 2012).

Zohrabi, Sabouri, and Kheradmand (2014) comment that "textbooks are one of the elements that may promote or discourage learners depending on their materials. They are a kind of support for both teachers and learners. Textbooks provide students a kind of consistency" (p. 95). They have an important influence in the instructional process. ELT textbooks have a major function in the second/foreign language teaching and learning domain. Sheldon (1988) states that textbooks represent the visible heart of any ELT program. Textbooks are an almost universal component of English language teaching. ELT textbooks play the role of a teacher, a map, a resource, a restrictor, and function as an ideology (Cortazzi \& Jin, 1999). Textbooks hold a paramount status as an indispensable ingredient of the language teaching profession; therefore, appraising and evaluating them seems to be imperative to assure their efficiency and consistency with the objectives defined and expected of the course. Constant evaluation of textbooks to see if they are appropriate is of great importance. This process enables us to make informed decisions through which student achievement will increase and educational programs will be more successful (Zohrabi, Sabouri, \& Behroozian, 2012). According to Ahour and Ahmadi (2012), textbooks give suitable knowledge to the learners. 
IJAMSR 2 (2) www.ijamsr.com CrossRef: https://doi.org/10.31426/ijamsr.2019.2.2.1221

\section{International Journal of Advanced Multidisciplinary Scientific Research (IJAMSR) ISSN:2581-4281}

Hutchinson and Torres (1994) suggest that "the textbook is an almost universal element of English language teaching and no teachinglearning situation, it seems, is complete until it has its relevant textbook" (p. 320). Textbooks as good assistants of the teachers help students learn different subject matters. They are the building blocks of school instruction (Azizifar, Koosha, \& Lotfi, 2010). Richards (2001) suggests that textbooks play two roles in different situations: they may be the basis for the content of the lesson in some situations, and may be a complement to the teacher's instruction in other situations. So any ELT program can be represented in textbooks, and most of the language input given to the students in the classroom comes from textbooks, too. In many EFL contexts, including Iran, the textbook may serve as the main source of contact learners have with the language, in addition to the input provided by the teacher.

Subsequently, in order to choose an applicable textbook that fulfills the needs of the learners according to their culture, textbook evaluation is required. Textbook evaluation is an essential aspect of EFL teaching. According to Richards and Schmidt (2010), evaluation is defined as "the systematic gathering of information for purposes of decision making" (p. 206). Ellis (1997) explicitly states that language teachers are faced with the task of choosing what teaching materials to use. The teachers are required to accomplish a predictive evaluation of the materials available to them to determine which are best appropriate to their objectives. Next, when the language teachers have used the materials, they may feel the need to undertake a further evaluation to determine whether the materials have 'worked' for them. This constitutes a retrospective evaluation. Several textbooks are produced annually across the globe and this wide range of textbooks are designed mainly for ESL/EFL situations. This variation leads to some confusion among teachers, especially those with little or no experience. Even experienced teachers might find it a daunting task to select a textbook for their target groups. Chambers (1997) says that the selection of materials to be used jointly in an ELT class should be selected by as wide range of users as possible. Therefore, selection and evaluation of textbooks are interrelated and considered to be a real problem for teachers and curriculum developers as well. Those who are working on textbook selection should bear in mind the target learners' needs and level, and a collective decision should be reached before prescribing a textbook. Selection, as I 
IJAMSR 2 (2) www.ijamsr.com CrossRef: https://doi.org/10.31426/ijamsr.2019.2.2.1221

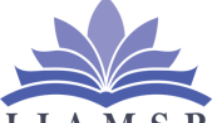

\section{International Journal of} Advanced Multidisciplinary Scientific Research (IJAMSR) ISSN:2581-4281

have noted above, involves evaluation in the first instance. Teachers are going through the textbook and some checklists have to be satisfied regarding the students' needs, the objectives of the course, and the context in which the textbook is to be taught. Whether evaluation takes place at the time of selecting the textbook or in a later stage, that is, after teaching it for a long time, it is a timeconsuming task and it has to be done carefully and patiently. Anyway, the main purpose of selection and evaluation is to enhance the conditions of English language teaching (ELT).

\section{Statement of the Problem}

Textbooks can be considered as an important factor in second /foreign language learning. According to Richards and Schmidt (2010), a textbook is defined as "a book on a specific subject used as a teaching/learning guide, especially in a school or college " (p. 595). Richards and Schmidt state that EFL textbooks usually constitute part of a graded series, which covers either multiple skills (i.e., listening, reading, writing, speaking) or just a single skill, such as, reading. Textbooks play an important role in the realm of language teaching and learning and they are regarded the next important factor in the second/foreign language classroom after the teacher (Riazi, 2003). In designing an English textbook, learners' needs and interests should be taken into consideration.

Materials evaluation is regarded as a pedagogical indispensable since it reveals how the quality of a textbook can be increased. Teaching materials directly affect the learning and teaching process and according to Nunan (1988) materials are an essential element within the curriculum, and do more than simply lubricate the wheels of learning. At their best, they provide concrete models for desirable classroom practice. They act as curriculum models and at their very best; they fulfill a teacher's development role.

\section{Literature Review}

In the related literature, different research studies have been conducted to evaluate textbooks. Amerian (1987, cited in Razmjoo, 2007) carried out a comparative study of the first two books of Right Path to English and Books One and Two of the Graded English series based on Tucker's (1975) model. Tucker (1975) proposes four main categories for evaluating a textbook. These are based on four linguistic, psychological, and pedagogical 
IJAMSR 2 (2) www.ijamsr.com CrossRef: https://doi.org/10.31426/ijamsr.2019.2.2.1221

\section{International Journal of Advanced Multidisciplinary Scientific Research (IJAMSR) ISSN:2581-4281}

principles. He uses three scales for rating in his model: The Value Scale (VS), The Merit Scale (MS), and The Value Merit Product (VMP). Amerian's study showed no significant differences between the two series. This was due to the fact that the two series represented the structural syllabus and design.

Ansary and Babaii (2002) examined a corpus of $10 \mathrm{EFL} / \mathrm{ESL}$ textbook reviews in addition to 10 EFL/ESL textbook evaluation checklists. Then, they made a list of the common core features of standard EFL/ESL textbooks. The main categories were outlined as an approach, content, presentation, physical make-up, and administration. They further divided each set of the main features of EFL/ESL textbooks into a number of subcategories. In the conclusion, it was mentioned that not all of these characteristics would be present in each and every textbook. Moreover, Yarmohammadi (2002) analyzed the senior high school textbooks based on a modified version of Tucker's model. He came to the conclusion that these textbooks suffer a lot of shortcomings. The weaknesses are: a) they are not authentic. b) English and Persian names are used interchangeably. c) Oral skills are ignored.
Amalsaleh (2004) adopted Van Leeuwen's model (1996) in order to evaluate three types of textbooks, including junior and senior high school textbooks with respect to the presence of social factors. The results revealed that the textbooks demonstrated a deferential representation of social factors. Junior and senior high school textbooks tended to shape normative perspectives towards gender-specific issues and class relations in which a middleclass urban male was considered to be the norm. This paper tried to evaluate an ESP textbook written for bachelor students of physics entitled 'English for the Students of Physics' which was prepared by the Center for Studying and Compiling University Books in Humanities (SAMT).

Sajjadi and Hadavi Nia (2011) tried to evaluate an ESP textbook written for bachelor students of physics entitled English for the Students of Physics which is prepared by SAMT. The research was based on qualitative and quantitative research techniques and included two steps. First, internal, external, and overall evaluation of the book was carried out based on McDonough and Shaw's (2003) model. In the second step, the perceptions of six teachers toward different aspects of the textbook were elicited using 22-item textbook evaluation 
IJAMSR 2 (2) www.ijamsr.com CrossRef: https://doi.org/10.31426/ijamsr.2019.2.2.1221

\section{International Journal of Advanced Multidisciplinary Scientific Research (IJAMSR) ISSN:2581-4281}

questionnaire. The results revealed the appropriateness of the textbook used by bachelor students of physics. Suggestions were offered for the future revision and/or designing textbooks.

Shafiee Nahrkhalaj (2012) examined the merits and demerits of EFL textbooks and explained two different sorts of textbooks used in Iran: global materials and institutional or in-house materials. In this study, Shafiee Nahrkhalaj presented a framework with a two-phase scheme for evaluation, which contained whilstuse and post-use evaluation. To obtain greater reliability, each norm was analyzed at a time by using planned instruments. He chose Top Notch series (Salslow \& Ascher, 2006) which has recently become very popular in main cities of the country. The textbook was evaluated using a checklist in two phases. The first phase included the attractiveness and the availability of the materials, the suitability of the exercises and tasks, the practicality of the textbook, the effectiveness in facilitating shortterm learning, the clarity of instructions, and the comprehensibility of the text. In phase two, long-term effects of the materials for the students were examined. Twenty teachers who had experience in teaching Top Notch series completed the questionnaire which included questions about the effects of using the material. With regard to the result of his study, the textbooks helped the learners find their aims to a great extent and it could improve the linguistic proficiency of the learners. Based on the teachers' opinions, it was concluded that all skills were covered in this textbook.

Davari, Iranmehr, and Erfani (2013) conducted a research study on Payam Nour University (PNU) ESP textbooks. The research intended to critically evaluate the current status of the Iranian ESP textbooks developed and published by PNU, as the. Second ESP textbook developer in the Iranian academic setting. The study tried to: (1) study the importance of ESP materials development and evaluation; (2) introduce the essential drawbacks which PNU textbooks suffer from; and (3) present some practical suggestions and solutions to tackle the significant problems and drawbacks of such ESP textbooks. Danaye Tous and Haghighi (2014) did another research study on ESP textbooks of Payame Noor University. The purpose of this study was to evaluate the ESP textbook "English for the Students of Computer Engineering" taught at Payame Noor University in Astane (Guilan province, Iran). Findings indicated that despite having pedagogical values, the textbook was 
IJAMSR 2 (2) www.ijamsr.com CrossRef: https://doi.org/10.31426/ijamsr.2019.2.2.1221

\section{International Journal of Advanced Multidisciplinary Scientific Research (IJAMSR) ISSN:2581-4281}

not very well, according to design and organization, language content and exercises, skills and strategies, practical considerations, and illustrations.

Because English is a very important part of the academic education of Iranian students, English textbooks have great effect on their future academic and professional progress. For that reason, the analysis of language teaching materials (the English textbooks) should be taken into consideration by language teachers and the researchers in the domain. Many studies (e.g., Amirian, \& Tavakoli, 2009; Baleghizadeh, \& Rahimi, 2011; Danaye Tous, \& Haghighi, 2014; Davari, Iranmehr, \& Erfani, 2013; Eslami-Rasekh, 2010; Jahangard, 2007; Manoochehri, \& Nemati, 2016; Razmjoo, 2007; Riazi, \& Mosallanejad, 2010; Sahragard, Rahimi, \& Zaremoayedi, 2009; Sajjadi \& Hadavi Nia 2011; Salehi, Davari, \& Yunus, 2015) have been conducted on analyzing English Textbooks. However, to the best of researcher's knowledge, no research study has attempted to analyze the new English textbook for tenth grade in Iranian high schools. For this reason, the present study is designed to evaluate the tenth grade English textbook based on some well-known course book evaluation criteria.
The significance of this study is to inform the probable weaknesses and challenges of the new English textbook for tenth grade in Iranian high schools from the perspective of EFL teachers. As a result, teachers, students, researchers, and material developers can benefit from the findings of the current research.

In the field of teaching English as a foreign language (TEFL), there are many textbooks in the market places. The English teachers have to take into account the necessary factors involved in selecting appropriate textbooks. It seems that making a good choice is a challenge to the teachers. Due to the policy in the ministry of education in Iran, the EFL teachers have to adapt the $10^{\text {th }}$ grade English textbook for their students. Therefore, the findings of this study can be beneficial for teachers because they can make an informed choice. Further, this study may draw the attention of material developers to the importance of a well-designed textbook for the $10^{\text {th }}$ grade high school students. 
IJAMSR 2 (2) www.ijamsr.com CrossRef: https://doi.org/10.31426/ijamsr.2019.2.2.1221

\section{International Journal of Advanced Multidisciplinary Scientific Research (IJAMSR) ISSN:2581-4281}

\section{Research Questions}

In order to achieve this purpose, six research questions were formulated:

a) Is the appearance of the book appropriate for the $10^{\text {th }}$ grade high school level?

b) Is the content of the book appropriate for the $10^{\text {th }}$ grade high school level?

c) Do the objectives of the course book correspond to the objectives of the English teaching program in the $10^{\text {th }}$ grade high school?

d) Does the book cover all the language skills?

e) Does the book cover all the language elements?

f) Are the activities of the book appropriate for the $10^{\text {th }}$ grade high school level?

\section{Method}

\section{Participants}

Participants were needed to attend two stages of this study: the questionnaire stage and the interview stage. The participants on the questionnaire stage were 80 female and male high school teachers (including 62 female and
18 male teachers) who taught the 10th grade high school English textbook in Tehran, Iran. The teachers varied in age from 28 to 49 years old and they had the same native language which was a Persian. A total number of 48 participants were educated in teaching English as a foreign language (TEFL) during their higher education while the other 32 teachers were educated in English literature and translation studies. The teachers were selected from six high schools, including Narjes, Jami, Hannan, Farzanegan, Ali Shariati, and Imam Khomeini high schools in Tehran. For the interview stage, 20 of these 80 teachers were selected randomly to be interviewed based on the interview protocol. The selected teachers had been teaching the tenth grade English textbook in Tehran for several years. The teachers varied in age from 28 to 37 years old. Most of them were educated in TEFL during their higher education.

\section{Instruments}

The questionnaire was the one prepared by Beydokhtinezhad, Azarnoosh, and Abdolmanafi-Rokni (2015). Beydokhtinezhad et al. adopted this questionnaire from a checklist by Tomilson, et al. (2002) and a course book assessment instrument by Al- 
IJAMSR 2 (2) www.ijamsr.com CrossRef: https://doi.org/10.31426/ijamsr.2019.2.2.1221

\section{International Journal of Advanced Multidisciplinary Scientific Research (IJAMSR) ISSN:2581-4281}

Hajailan (2003). The questionnaire has an introductory part aimed to gather the participants' demographic information. This 34-item questionnaire consists of seven parts relating to:
a) Physical appearance,
b) Content of the book,
c) Language skills,
d) Language elements,
e) Activities,
f) Supplementary materials, and
g) Objectives.

Each of these parts contains five or six items. The questionnaire is a five-point Likert scale instrument and the scales range from strongly disagree (1) to strongly agree (5). It should be noted that the researcher omitted the supplementary material section of the original form of the questionnaire. Therefore, the final questionnaire used in this study consisted of 31 items. The participants were asked to fill the questionnaire based on the extent to which they agreed with the questionnaire's statements. The "strongly agree" choice received 5 points and the "strongly disagree" option received 1 point.
The interview protocol consists of six general questions, attempting to elicit information from the teachers about the $10^{\text {th }}$ grade course book. The questions are related to the six categories of the question and their purpose is to elicit more information from the teachers about any of the questions. They are, therefore, concerned with the teachers' ideas about the appearance, content, and objectives of the course book, and the language skills and elements contained in the course book, and the activities included in it.

\section{Design}

The current study evaluated the English textbook taught at Iranian high schools in the 10th grade. Therefore, this study was a descriptive research in nature. Descriptive research provides a picture of a phenomenon as it naturally occurs, as opposed to studying the impacts of the phenomenon or intervention. Descriptive research attempts to look at individuals, groups, institutions, methods and materials in order describe, compare, contrast, classify, analyze, and interpret the entities and events. It is concerned with the conditions or relationships that exist; practices that prevail; beliefs, points of views, or attitudes that are held; processes that are going on; effects that are being felt; or trends that are developing. At 
IJAMSR 2 (2) www.ijamsr.com CrossRef: https://doi.org/10.31426/ijamsr.2019.2.2.1221

\section{International Journal of Advanced Multidisciplinary Scientific Research (IJAMSR) ISSN:2581-4281}

times, descriptive research is concerned with how what is or what exists is related to some preceding event that has influenced or affected a present circumstance or event (Mackey and Gass 2005; Tavakoli, 2012).

\section{Material}

The ministry of education of Iran has proclaimed a so-called fundamental reform of the education system since 2010 and the most important stage toward accomplishing this reform was the preparation of "National curriculum of Islamic Republic of Iran," finally confirmed in late 2012. This national curriculum consists of 12 educational areas and the 11th domain is devoted to teaching foreign languages. This is the first time that the informal education system of Iran a set of goals for teaching foreign languages is determined and officially proclaimed by the ministry of education.

The English textbook in the present study was called "Vision 1: English for Schools". The textbook was written by Alavi Moghaddam, Kheirabadi, Rahimi, Davari (2016). It was prepared under supervision of organization for educational research and planning, the Ministry of Education of Iran.

\section{Procedure}

First, the participants were selected to participate in this study. Next, the participants were asked to complete the before-mentioned questionnaire. Then, 20 of the EFL teachers were selected randomly and were interviewed based on the interview protocol.

\section{Results}

\section{Results of the Questionnaire Stage}

\section{Reliability of the Questionnaire}

The reliability of the questionnaire sections (i.e., appearance, contents, objectives, language skills, language elements, and activities) was estimated based on a score from 15 subjects similar in characteristics to target subjects. KR21 statistical analysis was used to estimate the reliability of the questionnaire sections.

Table 1: Statistics related to Piloting of the Instruments of this Study

\begin{tabular}{|l|c|c|}
\hline Instrument Sections & No. of Items & 'r' \\
\hline Appearance & 5 & 0.751 \\
Contents & 6 & 0.711 \\
Objectives & 5 & 0.801 \\
Language Skills & 6 & 0.781 \\
Language Elements & 4 & 0.704 \\
Activities & 5 & 0.815 \\
\hline
\end{tabular}


International Journal of Advanced Multidisciplinary Scientific Research (IJAMSR) ISSN:2581-4281 Volume 2, Issue 2, February, 2019

IJAMSR 2 (2) www.ijamsr.com CrossRef: https://doi.org/10.31426/ijamsr.2019.2.2.1221

\section{International Journal of}

I J A M S R

\section{Advanced Multidisciplinary Scientific Research (IJAMSR) ISSN:2581-4281}

Based on the results from table 1, the instrument's sections used in the present study had an acceptable range of reliability.

\section{Descriptive Statistics}

\section{Frequency Distribution of the Sample}

In table 2, the frequency and percentage of the participants in each group are presented.

\begin{tabular}{|l|c|c|c|c|c|}
\hline \multicolumn{1}{|c|}{ Sections } & Subjects & Items & Mean & Min & Max \\
\hline Appearance & 80 & 5 & 20.20 & 9 & 25 \\
\hline Content & 80 & 6 & 21.50 & 8 & 25 \\
\hline Objectives & 80 & 5 & 9.10 & 5 & 13 \\
\hline $\begin{array}{l}\text { Language } \\
\text { Skills }\end{array}$ & 80 & 6 & 23.00 & 6 & 23 \\
\hline $\begin{array}{l}\text { Language } \\
\text { Elements }\end{array}$ & 80 & 4 & 18.30 & 7 & 16 \\
\hline Activities & 80 & 5 & 7.40 & 5 & 15 \\
\hline
\end{tabular}

Table 2: Distribution and Frequency Percent of the Participants.

\begin{tabular}{|l|c|c|c|}
\hline \multicolumn{1}{|c|}{ Sample } & Frequency & $\begin{array}{c}\text { Frequency } \\
\text { Percent }\end{array}$ & $\begin{array}{c}\text { Cumulative } \\
\text { Frequency } \\
\text { Percent }\end{array}$ \\
\hline $\begin{array}{l}\text { Female } \\
\text { Teachers }\end{array}$ & 62 & 76.5 & 75 \\
\hline $\begin{array}{l}\text { Male } \\
\text { Teachers }\end{array}$ & 18 & 23.5 & 100 \\
\hline Sum & 80 & 100 & \\
\hline
\end{tabular}

As can be seen in table 2, 75 percent of the participants were female high school teachers and 25 percent of the members of the present study were male teachers.

\section{Descriptive Statistics for the Questionnaire} Scores

Table 3: Descriptive Statistics for the Questionnaire Scores.

Based on the results shown in Table 3, the mean of the teachers' scores toward appearance, content, objectives, language skills, language elements and activities were $20.20,21.50,9.10,23.00,18.30$ and 7.40 respectively.

\section{Data Normality}

In this study, Kolmogorov-Smirnov test was run to examine the normality of data distribution.

Table 4: Normality Test of Data Distribution

\begin{tabular}{|c|c|c|}
\hline & $\begin{array}{c}\text { Kolmogorov- } \\
\text { Smirnov }\end{array}$ & \\
\hline & $\begin{array}{c}\text { Kolmogorov- } \\
\text { Smirnov }\end{array}$ & Sig. \\
\hline $\begin{array}{c}\text { The Questionnaire } \\
\text { Scores }\end{array}$ & 0.187 & 0.201 \\
& & \\
\hline
\end{tabular}


IJAMSR 2 (2) www.ijamsr.com CrossRef: https://doi.org/10.31426/ijamsr.2019.2.2.1221

\section{International Journal of Advanced Multidisciplinary Scientific Research (IJAMSR) ISSN:2581-4281}

According to the results presented in Table 4, as the significance level of the teachers' scores toward the questionnaire's variable was greater than $0.05(\mathrm{p}>0.05)$, it was concluded that the teachers' scores had a normal distribution.

\section{Inferential Statistics}

\section{Hypotheses Testing}

In order to investigate the hypotheses of the present study, the parametric test should be used because the participants' scores on the questionnaire had a normal distribution. In order to test the hypotheses, a series of onesample t-tests were used. In one-sample t-test, if the significance level is greater than error value 0.05 ( $\mathrm{sig}>0.05)$ and also the t-statistics is less than $1.96(\mathrm{t}<1.96)$, it can be concluded that the related hypothesis cannot be rejected. 1.96 is the approximate value of the 97.5 percentile points of the normal distribution used in probability and statistics. 95\% of the area under a normal curve lies within roughly 1.96 standard deviations of the mean, and due to the central limit theorem, this number is therefore used in the construction of approximate $95 \%$ confidence intervals. Its ubiquity is due to the arbitrary but the common convention of using confidence intervals with 95\% coverage rather than other coverages.

\section{Testing Hypothesis 1}

The first hypothesis of the study was "the appearance of the book is not appropriate for the 10th grade high school level". Thus, in order to test the research hypothesis, the following data analysis procedure is as follows:

Table 5: One-sample Statistics for Appearance of the Book.

\begin{tabular}{|c|c|c|c|c|c|}
\hline Variable & $\mathrm{N}$ & Items & $\mathrm{M}$ & SD & SEM \\
\hline Appearance & 80 & 5 & 20.20 & 1.58 & 2.140 \\
& & & & & \\
\hline
\end{tabular}

Table 6: One-sample test for the Appearance of the Book.

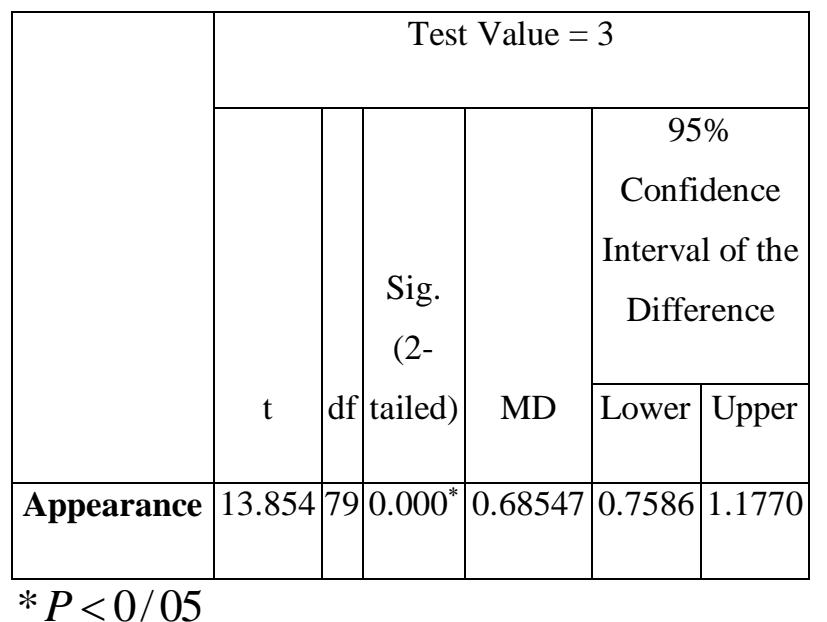


IJAMSR 2 (2) www.ijamsr.com CrossRef: https://doi.org/10.31426/ijamsr.2019.2.2.1221

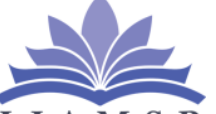

\section{International Journal of} Advanced Multidisciplinary Scientific Research (IJAMSR) ISSN:2581-4281

Based on the results of Table 6 , the significance level was 0.000 and it was less than the error value $(\mathrm{p}<0.05)$. In addition, the t-statistics were 13.854 which was greater than $1.96(t>1.96)$. It could be concluded that the mean of the participants' scores in the appearance items of the questionnaire had meaningful difference with "3," $\mathrm{t}(79)=13.85$, $\mathrm{p}=.00$. Moreover, it was observed that the mean of the participants' scores in the appearance items was 20.20 which was greater than "15" which is the mean of the appearance items (5 items). According to the findings, the teachers believed that the appearance of the book was appropriate for the tenth grade high school students. Therefore, the first research null hypothesis was rejected.

\section{Testing Hypothesis 2}

"The content of the book is not appropriate for the 10th grade high school level" was the second hypothesis.

Table 7: One-sample Statistics for Content of the Book

\begin{tabular}{|c|c|c|c|c|c|}
\hline & $\mathrm{N}$ & Items & $\mathrm{M}$ & $\mathrm{SD}$ & SEM \\
\hline Content & 80 & 6 & 21.50 & 1.09 & 3.245 \\
& & & & & \\
\hline
\end{tabular}

Table 8: One-sample Test for Content of the Book

\begin{tabular}{|c|c|c|c|c|c|c|}
\hline & \multicolumn{6}{|c|}{ Test Value $=3$} \\
\hline & \multirow[b]{2}{*}{$\mathrm{t}$} & \multirow{2}{*}{\multicolumn{2}{|c|}{\begin{tabular}{l|l} 
& Sig. (2- \\
df & tailed)
\end{tabular}}} & \multirow[b]{2}{*}{ MD } & \multicolumn{2}{|c|}{$\begin{array}{c}95 \% \text { Confidence } \\
\text { Interval of the } \\
\text { Difference }\end{array}$} \\
\hline & & & & & Lower & Upper \\
\hline Content & 9.957 & 79 & $0.000^{*}$ & 0.75849 & 1.0057 & 2.1254 \\
\hline
\end{tabular}

Table 8 shows the significance level was 0.000 $(\mathrm{p}=0.000)$ and it was less than the error value $(\mathrm{p}<0.05)$. In addition, the t-statistics were 9.957 which was greater than $1.96(\mathrm{t}>1.96)$. It could be concluded that the mean of the participants' scores in the content items of the questionnaire had meaningful difference with "3". Moreover, it was observed that the mean of the participants' scores in the content items was 21.50 which was greater than "18". Based on the findings, the teachers believed that the content of the book was appropriate for the tenth grade high school level. Therefore, the second research null hypothesis was rejected, too. 
IJAMSR 2 (2) www.ijamsr.com CrossRef: https://doi.org/10.31426/ijamsr.2019.2.2.1221

\section{International Journal of Advanced Multidisciplinary Scientific Research (IJAMSR) ISSN:2581-4281}

\section{Testing Hypothesis 3}

In this study, the third research hypothesis was "the objectives of the course book do not correspond to the objectives of the English teaching program in the 10th grade high school".

Table 9: One-sample Statistics for Objectives of the Book

\begin{tabular}{|l|c|c|c|c|c|}
\hline & $\mathrm{N}$ & Items & $\mathrm{M}$ & $\mathrm{SD}$ & $\mathrm{SEM}$ \\
\hline Objectives & 80 & 5 & 9.10 & 0.578 & 1.245 \\
& & & & & \\
\hline
\end{tabular}

Table 10: One-sample Test for Objectives of the Book

\begin{tabular}{|c|c|c|c|c|c|c|}
\hline & \multicolumn{6}{|c|}{ Test Value $=3$} \\
\hline & \multirow[b]{2}{*}{$\mathrm{T}$} & \multirow{2}{*}{\multicolumn{2}{|c|}{ df $\mid \begin{array}{l}\text { Sig. (2 } \\
\text { tailed) }\end{array}$}} & \multirow[b]{2}{*}{ MD } & \multicolumn{2}{|c|}{$\begin{array}{c}95 \% \\
\text { Confidence } \\
\text { Interval of the } \\
\text { Difference }\end{array}$} \\
\hline & & & & & Lower & Upper \\
\hline Objectives & 0.9854 & 79 & $0.090^{*}$ & 0.58648 & 0.3212 & 0.9825 \\
\hline
\end{tabular}

$* P<0 / 05$

Table 10 shows the significance level was $0.090(\mathrm{p}=0.090)$ and it was greater than the error value $(\mathrm{p}<0.05)$. In addition, the $\mathrm{t}$ - statistics were 0.9854 which was greater than $1.96(\mathrm{t}>1.96)$. It could be concluded that the mean of the participants' scores in the objective items of the questionnaire had meaningful difference with "3". Therefore, the second research null hypothesis were accepted. Moreover, it was observed that the mean of the participants' scores in the content items was 9.10 which was less than "15". Although the difference was not significant, based on the findings, the teachers thought the objectives of the course book did not correspond to the objectives of the English teaching program in the 10th grade high school.

\section{Testing Hypothesis 4}

The forth research hypothesis was "the book does not cover all the language skills".

Table 11: One-sample Statistics for Language Skills of the Book

\begin{tabular}{|c|c|c|c|c|c|}
\hline & $\mathrm{N}$ & Items & M & SD & SEM \\
\hline Language & & 6 & & & \\
\hline Skills & 80 & & 23.00 & 2.587 & 2.3546 \\
\hline
\end{tabular}


IJAMSR 2 (2) www.ijamsr.com CrossRef: https://doi.org/10.31426/ijamsr.2019.2.2.1221

\section{International Journal of Advanced Multidisciplinary Scientific Research (IJAMSR) ISSN:2581-4281}

Table 12: One-sample Test for Language Skills of the Book

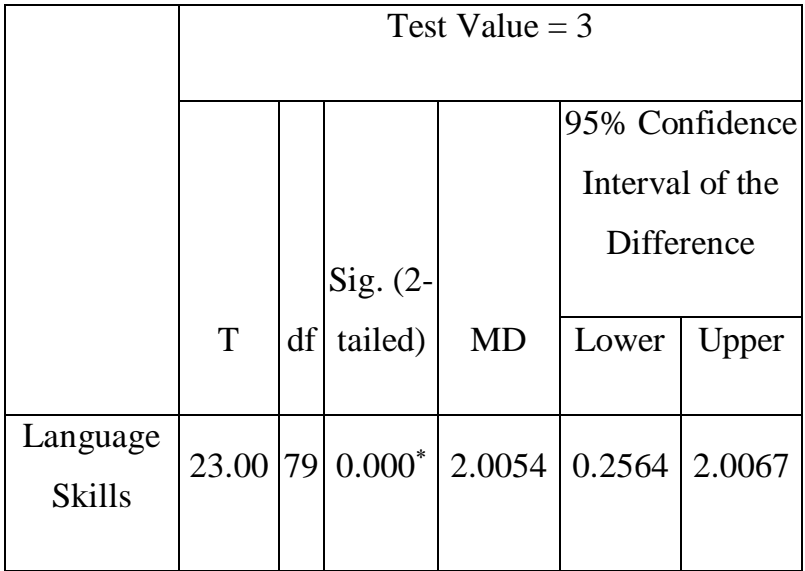

$* P<0 / 05$

Based on obtaining results from Table 12, the significance level was $0.000(\mathrm{p}=0.000)$ and it was less than the error value $(\mathrm{p}<0.05)$. In addition, the t-statistics were 23.00 which was greater than $1.96(t>1.96)$. It could be concluded that the mean of the participants' scores in the language skills items of the questionnaire had meaningful difference with "3". Moreover, it was observed that the mean of the participants' scores in the language skills items was 23.00 which was greater than "18". Based on the findings, the teachers believed that the book did cover all the language skills. Therefore, the forth research null hypothesis was rejected.

\section{Testing Hypothesis 5}

"The book does not cover all the language elements" was the fifth research hypothesis in this study.

Table 13: One-sample Statistics for Language Elements of the Book

\begin{tabular}{|l|c|c|c|c|c|}
\hline & $\mathrm{N}$ & Items & $\mathrm{M}$ & $\mathrm{SD}$ & SEM \\
\hline Language \\
Elements & 80 & & 18.30 & 2.004 & 3.200 \\
\hline
\end{tabular}

Table 14: One-sample Test for Language Elements of the Book

\begin{tabular}{|c|c|c|c|c|c|c|}
\hline & \multicolumn{6}{|c|}{ Test Value $=3$} \\
\hline & \multirow[b]{2}{*}{$\mathrm{t}$} & \multirow[b]{2}{*}{ df } & \multirow{2}{*}{$\begin{array}{l}\text { Sig. (2- } \\
\text { tailed) }\end{array}$} & \multirow[b]{2}{*}{ MD } & \multicolumn{2}{|c|}{$\begin{array}{c}95 \% \text { Confidence } \\
\text { Interval of the } \\
\text { Difference }\end{array}$} \\
\hline & & & & & Lower & Upper \\
\hline $\begin{array}{l}\text { Language } \\
\text { Elements }\end{array}$ & 8.001 & 79 & $0.000^{*}$ & 1.0824 & 0.0958 & 0.8010 \\
\hline
\end{tabular}

Table 14 shows the significance level was $0.000(\mathrm{p}=0.000)$ and it was less than the error value $(\mathrm{p}<0.05)$. In addition, the $\mathrm{t}$-statistics were 8.001 which was greater than $1.96(\mathrm{t}$ > 1.96). It could be concluded that the mean of 
IJAMSR 2 (2) www.ijamsr.com CrossRef: https://doi.org/10.31426/ijamsr.2019.2.2.1221

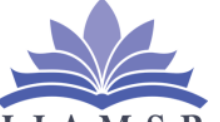

\section{International Journal of} Advanced Multidisciplinary Scientific Research (IJAMSR) ISSN:2581-4281

the participants' scores in the language element items of the questionnaire had meaningful difference with "3". Moreover, it was observed that the mean of the participants' scores in the language element items was 18.30 which was greater than "12". Based on the findings, the teachers believed that the book covered all the language elements. Therefore, the fifth research null hypothesis was rejected, too.

\section{Testing Hypothesis 6}

The sixth research hypothesis was "the activities of the book are not appropriate for the 10th grade high school level".

Table 15: One-sample Statistics for Activities of the Book

\begin{tabular}{|c|c|c|c|c|c|}
\hline & $\mathrm{N}$ & Items & $\mathrm{M}$ & SD & SEM \\
\hline Activities & & 5 & & & \\
\hline & 80 & & 7.40 & 0.026 & 1.003 \\
\hline
\end{tabular}

Table 16: One-sample Test for Activities of the Book

\begin{tabular}{|c|c|c|c|c|c|c|}
\hline & \multicolumn{6}{|c|}{ Test Value $=3$} \\
\hline & \multirow[b]{2}{*}{$\mathrm{T}$} & \multirow{2}{*}{\multicolumn{2}{|c|}{ df $\left|\begin{array}{l}\text { Sig. (2- } \\
\text { tailed) }\end{array}\right|$}} & \multirow[b]{2}{*}{ MD } & \multicolumn{2}{|c|}{$\begin{array}{c}95 \% \text { Confidence } \\
\text { Interval of the } \\
\text { Difference }\end{array}$} \\
\hline & & & & & Lower & Upper \\
\hline Activities & 1.006 & 79 & $0.101^{*}$ & 0.08440 & 0.2122 & \begin{tabular}{|l|}
1.0090 \\
\end{tabular} \\
\hline
\end{tabular}

Table 16 shows the significance level was $0.101(\mathrm{p}=0.101)$ and it was greater than the error value $(\mathrm{p}<0.05)$. In addition, the $\mathrm{t}$ statistics were 1.006 which was less than 1.96 $(t>1.96)$. It could be concluded that the mean of the participants' scores in the actionable items of the questionnaire did not have meaningful difference with "3". Therefore, the last research null hypothesis could not be rejected. Moreover, it was observed that the mean of the participants' scores in the activities items was 7.40 which was less than "15". Based on the findings, the activities of the book were not appropriate for the 10th grade high school students. 
IJAMSR 2 (2) www.ijamsr.com CrossRef: https://doi.org/10.31426/ijamsr.2019.2.2.1221



\section{Advanced Multio
Interview Stage}

International Journal of

The interview protocol of the present study included six general domains (i.e., appearance, content, activities, objectives, language skills, and elements). In the following, some examples of the teachers' statements are presented. The first question was about appearance of the book.

Mrs. Mohammadi was asked the first question and she said:

"The size of the book is good. I prefer the large size".

Moreover, the Mr. Alemi was asked the same question and he answered:

"I should say it is somehow philosophical; its perception is difficultfor the students".

\section{Results of the Interview Stage} perception is difficult for

The second interview question was about the content of the book, whether they are well formed and attract the students.

Mrs. Khodaie was asked the question and she answered:

"To me, the content of the book is suitable for the tenth grade high school students because it is understandable for the learners".
In this regard, Mrs. Jalali had the same idea and stated:

"The content of the book is appropriate for the students".

The third interview question was about the objectives of the book.

"Mrs. Mousavi was asked the question and she said:

"Objectives of the course book do not correspond to the objectives of the English teaching program in the 10th grade high school because all objectives are not achieved after finishing the book".

The fourth question of the interview was related to the language skills of the textbook.

"To me, the textbook does cover all the language skills" Mr. Goudarzi said.

The fifth question of the interview was related to the language elements.

Mrs. Koliaei was asked the question and she answered:

"Similar to the language skills, the textbook does cover all the language elements". 
IJAMSR 2 (2) www.ijamsr.com CrossRef: https://doi.org/10.31426/ijamsr.2019.2.2.1221

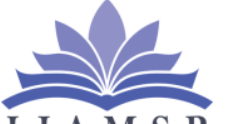

\section{International Journal of} Advanced Multidisciplinary Scientific Research (IJAMSR) ISSN:2581-4281

The last question was about the activities. The teachers were asked, whether the activities are suitable and sufficient.

Mrs. Darvishi was asked the last question and she said:

"In my opinion, the activities of the book are not appropriate for the 10th grade high school students because they are not comprehensive and do not cover all the book's parts".

The findings of the interview session indicated that the teachers believed that appearance and the content of the book were appropriate for the tenth grade high school students. Similarly, the text book did cover all the language skills and elements. On the other hand, the teachers thought that the activities of the book were not suitable for the students. Likewise, they believed that the objectives of the book did not match to the aims of the English teaching program in the 10th grade high school.

\section{Discussion of the Findings}

Based on data analysis procedure and the interview findings, it was revealed that the appearance and the content of the book were appropriate for the tenth grade high school students. On the other hand, the objectives of the course book did not correspond to the objectives of the English teaching program in the 10th grade high school. Moreover, the book did cover all the language skills and elements. At last, the activities of the book were not appropriate for the 10th grade high school students.

The findings of the study are in line with Ansary and Babaii (2002) who examined a corpus of 10 EFL/ESL textbook reviews in addition to $10 \mathrm{EFL} / \mathrm{ESL}$ textbook evaluation checklists. Obtained results revealed that not all of these characteristics would be present in each and every textbook. Moreover, Yarmohammadi (2002) analyzed the senior high school textbooks based on a modified version of Tucker's model. Having administered the research, Yarmohammadi found that these textbooks suffer a lot of shortcomings. For example, the textbooks are not authentic. Moreover, oral skills in the textbooks are ignored.

The findings of the study are in line with Amalsaleh (2004) who evaluated three types of textbooks, including junior and senior high school textbooks with respect to the presence of social factors. The results revealed that the 
IJAMSR 2 (2) www.ijamsr.com CrossRef: https://doi.org/10.31426/ijamsr.2019.2.2.1221

\section{International Journal of Advanced Multidisciplinary Scientific Research (IJAMSR) ISSN:2581-4281}

textbooks demonstrated a deferential representation of social factors. Junior and senior high school textbooks tended to shape normative perspectives towards gender-specific issues and class relations in which a middleclass urban male was considered to be the norm.

The findings of the present study agree with Sajjadi and Hadavi Nia (2011) who tried to evaluate an ESP textbook written for bachelor students of physics entitled English for the Students of Physics which is prepared by SAMT. The results revealed the extent of the appropriateness of the textbook used by bachelor students of physics. Likewise, Shafiee Nahrkhalaj (2012) examined the merits and demerits of EFL textbooks and explained two different sorts of textbooks used in Iran: global materials and institutions or in-house materials. The researcher found that the textbooks helped the learners find their aims to a great extent and it could improve the linguistic proficiency of the learners. Based on the teachers' opinions, it was concluded that all the skills were covered in this textbook.

The findings of the present study match Davari, Iranmehr, and Erfani (2013) who conducted a research study on Payam Nour
University (PNU) ESP textbooks. Similar to the findings of the present study, Danaye Tous and Haghighi (2014) did a research study in the field of study on ESP textbooks of Payame Noor University. The purpose of this study was to evaluate the ESP textbook "English for the Students of Computer Engineering" taught at Payame Noor University in Astane (Guilan province, Iran). Findings indicated that despite having pedagogical values, the textbook was not very well, according to design and organization, language content and exercises, skills and strategies, practical considerations, and illustrations.

\section{Conclusions}

The obtained results revealed that the appearance and the content of the book were appropriate for the tenth grade high school students. On the other hand, the objectives of the course book did not correspond to the objectives of the English teaching program in the 10th grade high school. Moreover, the book did cover all the language skills and elements. At last, the activities of the book were not appropriate for the 10th grade high school students. 
IJAMSR 2 (2) www.ijamsr.com CrossRef: https://doi.org/10.31426/ijamsr.2019.2.2.1221



\section{Advanced
of the Study}

I J A M S R

\section{International Journal of}

\section{Implications of the Study}

The findings of the present study hold important implications for textbook designers and English teachers, and high school students. The EFL teachers' attitudes towards tenth grade high school play a crucial role in the success of their students. By knowing teachers' attitudes towards the textbook, textbook designers and editors have a better understanding of what must be and not be included in the textbook and the next editions of the book will be mostly based on teachers' and learners' needs and requirements.

Conducting needs analysis helps textbook writers to improve their work and also develop and write the textbooks that are according to the learners' needs. Teachers can also be aware of the needs of the learners and pay enough attention to their requirements.

The findings of this study enable the textbook authors to adopt the textbook more relevant to the students' needs. The questionnaires used in this study to help the teachers gain a deeper insight in selecting the appropriate textbook.

Some points should be taken into consideration by textbook designers and editors while revising the textbook. They are put forth as follows: a) Improving individual learning.

b) Covering all four skills adequately to meet the needs of tenth grade high school students.

c) Giving more priority to written skills, especially reading passages and associative activities.

d) Emphasizing on authentic-based materials in different language skills and sub skills.

e) Providing materials that facilitate reallife interaction.

f) Modifying grammar items matched with the students' level.

g) Focusing much more attention on attractive appearance.

h) Revising and updating the textbook may be useful. Providing texts and tasks with newer concepts and information is necessary.

\section{Suggestions}

a) The generalizability of the findings may be limited since this research has examined only 80 teachers at different high schools in Tehran, Iran. Future studies may investigate the evaluation 
IJAMSR 2 (2) www.ijamsr.com CrossRef: https://doi.org/10.31426/ijamsr.2019.2.2.1221

\section{International Journal of} Advanced Multidisciplinary Scientific Research (IJAMSR) ISSN:2581-4281

of the textbook, utilizing a random sampling method with larger sample sizes. Maybe if all participants were chosen from different high schools all over the country, the results would be more generalizable.

b) In order to measure the questionnaire of the present study, 5 points Likert were used. Likert scaling is a bipolar scaling method, measuring either positive or negative response to a statement. Future studies could use other ways to measure the related questionnaire.

c) This study was primarily conducted to evaluate the English textbook taught at Iranian high schools in the tenth grade. Interested research could evaluate the English textbook taught at Iranian high schools for the eleven and twelve grades.

d) Future studies could explore Iranian high school students' views to evaluate the English textbook taught at Iranian high schools in the tenth grade.

e) Future research needs to spend a longer time than the time spent in this study.

\section{References}

1) Ahour, T., \& Ahmadi, E. (2012). Retrospective evaluation of textbook "Summit $2 B$ " for its suitability for EFL undergraduate students. Book of Proceedings of the International Conference on Human and Social Sciences, 6, 176-184.

2) Al Hajailan, D.T. (2003). Teaching English in Saudi Arabia. Riyadh: Aldar Alsawlatiah.

3) Alavi Moghaddam, S.B., Kheirabadi, R., Rahimi, M., \& Davari, R. (2016). The English text book Vision 1: English for Schools. Tehran: Ministry of Education of Iran.

4) Amalsaleh, E. (2004). The representation of social factors in the EFL textbooks in Iran. Unpublished doctoral dissertation, Shiraz University, Shiraz.

5) Amirian, Z., \& Tavakoli, M. (2009). Reassessing ESP courses offered to engineering studies in Iran. English for Specific Purposes World, 8(23), 1-13.

6) Azizifar, A., Koosha, M., \& Lotfi, A. R. (2010). An analytical evaluation of Iranian high school ELT textbooks from 1970 to the present. Procedia Social and Behavior al Sciences, 3, 36-44.

7) Baleghizadeh, S. \& Rahimi, A. H. (2011). Evaluation of an ESP textbook for the students of sociology. Journal of Language Teaching and Research, 2(5), 1009-1014.

8) Beydokhtinezhad, S., Azarnoosh, M., \& Abdolmanafi-Rokni, S. J. (2015). An exploration of high school teachers' evaluation of seventh and eighth grade English textbooks. Theory and Practice in Language Studies, 5(10), 2070-2075.

9) Chambers, F. (1997). Seeking consensus in course book evaluation. ELT Journal, 51(1), 29- 35.

10) Danaye Tous, M., \& Haghighi, S. (2014). Evaluation of ESP textbooks: Evidence from ESP textbook of computer engineering major. International Journal of Research Studies in Language Learning, 3(2), 55-68. 
IJAMSR 2 (2) www.ijamsr.com CrossRef: https://doi.org/10.31426/ijamsr.2019.2.2.1221

\section{International Journal of}

I J A M S R

\section{Advanced Multidisciplinary Scientific Research (IJAMSR) ISSN:2581-4281}

11) Davari, H., Iranmehr, A., \& Erfani, M. (2013). A Critical Evaluation of PNU ESP Textbooks. Journal of Language Teaching and Research, 4 (4), 813-823.

12) Ellis, R. (1997). The empirical evaluation of language teaching materials. ELT Journal, 51(1), 36-42.

13) Eslami-Rasekh, Z. R. (2010). Teachers' voice vs. students'voice: A needs analysis approach to English for academic purposes (EAP) in Iran. English Language Teaching, 3(1), 2-11.

14) Hutchinson, T., \& Torres, E. (1994). The textbook as agent of change. ELT Journal, 48(4), 315-328.

15) Jahangard, A. (2007). Evaluation of EFL materials taught at Iranian public high schools. Asian EFL Journal, 9 (2), 1-15.

16) Lotfi, B. (2005). Incorporating critical thinking activities in content areas (ESP/EAP). In G. R. Kiani \& M. Khayamdar (Eds.) Proceedings of the First National ESP/EAP Conference. Tehran, SAMT Publication.

17) Manoochehri, M. A., \& Nemati, A. (2016). Evaluation of computer engineering ESP course from students' viewpoints. British Journal of Education, Society \& Behavioral Science, 14 (2), 1-13.

18) McDonough, J. \& Shaw, Ch. (2003). Materials and methods in ELT: A teacher's guide. Oxford: Blackwell Publishing LTD.

19) Nunan, D. (1988). Learner-centered curriculum. Cambridge: Cambridge University Press.

20) Razmjoo, S. A. (2007). High schools or private institutes textbooks? Which fulfill communicative language teaching principles in the Iranian context? Asian EFL Journal, 9 (4), 77-95.

21) Riazi, A. M. (2003). What textbook evaluation schemes tell us? A study of the textbook evaluation schemes of three decades. In W. A. Renandya, (Ed.), Methodology and materials design in language teaching (pp.52-68). Singapore: SEAMEO Regional Center.
22) Riazi, A. M., \& Mosallanejad, N. (2010). Evaluation of learning objectives in Iranian high-school and pre-university English textbooks using Bloom's taxonomy. TESL EJ, 13 (4), 1-16.

23) Sahragard, R., Rahimi, A., \& Zaremoayedi, I. (2009). An in-depth evaluation of Interchange Series (3 ${ }^{\text {rd }}$ Ed.). Porta Linguarum, 12 (1), $37-$ 54.

24) Sajjadi, M., \& Hadavi Nia, V. (2011). Evaluating the SAMT English Textbook for BSC Students of Physics. The Journal of Applied Linguistics, 4 (2), 176-196.

25) Salehi, H., Davari, A., \& Yunus, M. (2015). Evaluation of an ESP course of Qur'anic sciences and tradition. International Education Studies, 8 (1), 29-37.

26) Shafiee Nahrkhalaji, S. (2012). An Evaluation of a global ELT textbook in Iran: A two-phase approach. International Journal of Humanities and Social Science, 2 (3), 184-191.

27) Sheldon, L.E. (1988). Evaluating ELT textbooks and materials. ELT Journal, 42(2), 237-246.

28) Van Leeuwen, T. (1996). Critical discourse analysis. In K. Brown (Ed.), Encyclopedia of language and linguistics (2 ${ }^{\text {nd }}$ ed., Vol. 3, pp. 290-294). Oxford: Elsevier.

29) Yarmohammadi, L. (2002). The evaluation of pre-university textbooks. The Newsletter of the Iranian Academy of Science, 18, 70-87.

30) Zohrabi, M., Sabouri, H., \& Behroozian, R. (2012). An assessment of strengths and weaknesses of Iranian first year high school English course book using evaluation checklist. English Language and Literature Studies, 2(2), 89-99.

31) Zohrabi, M., Sabouri, H., \& Kheradmand, M. (2014). Comparative study of interchange 1 and English book 1 of Iranian high schools. Education International Journal of English, 3(2), 95-104. 